\title{
No Nogo66- and NgR-Mediated Inhibition of Regenerating Axons in the Zebrafish Optic Nerve
}

\author{
Houari Abdesselem, ${ }^{\star}$ Aleksandra Shypitsyna, ${ }^{\star}$ Gonzalo P. Solis, ${ }^{\star}$ Vsevolod Bodrikov, and Claudia A. 0. Stuermer \\ Developmental Neurobiology, Department of Biology, University of Konstanz, D-78457 Konstanz, Germany
}

In contrast to mammals, lesioned axons in the zebrafish (ZF) optic nerve regenerate and restore vision. This correlates with the absence of the NogoA-specific N-terminal domains from the ZF nogo/rtn-4 (reticulon-4) gene that inhibits regeneration in mammals. However, mammalian nogo/rtn-4 carries a second inhibitory C-terminal domain, Nogo-66, being 70\% identical with ZF-Nogo66. The present study examines, (1) whether ZF-Nogo66 is inhibitory and effecting similar signaling pathways upon Nogo66-binding to the Nogo66 receptor $\mathrm{NgR}$ and its coreceptors, and (2) whether Rat-Nogo66 on fish, and ZF-Nogo66 on mouse neurons, cause inhibition via NgR. Our results from "outgrowth, collapse and contact assays" suggest, surprisingly, that ZF-Nogo66 is growth-permissive for ZF and mouse neurons, quite in contrast to its Rat-Nogo66 homolog which inhibits growth. The opposite effects of ZF- and Rat-Nogo66 are, in both fish and mouse, transmitted by GPI (glycosylphosphatidylinositol)-anchored receptors, including NgR. The high degree of sequence homology in the predicted binding site is consistent with the ability of ZF- and mammalian-Nogo66 to bind to NgRs of both species. Yet, Rat-Nogo66 elicits phosphorylation of the downstream effector cofilin whereas ZF-Nogo66 has no influence on cofilin phosphorylation-probably because of significantly different Rat- versus ZF-Nogo66 sequences outside of the receptor-binding region effecting, by speculation, recruitment of a different set of coreceptors or microdomain association of NgR. Thus, not only was the NogoA-specific domain lost in fish, but Nogo66, the second inhibitory domain in mammals, and its signaling upon binding to NgR, was modified so that ZF-Nogo/RTN-4 does not impair axon regeneration.

\section{Introduction}

In the mammalian CNS the attempts of lesioned axons to regrow are blocked by axon growth-inhibitory and -repulsive molecules associated with CNS myelin, oligodendrocytes (Schwab, 2004; Yiu and He, 2006), macrophages (Horn et al., 2008), and the glial scar (Silver and Miller, 2004). A potent inhibitory protein in oligodendrocytes and the mammalian CNS myelin is Nogo-A, the largest of three transcripts of the nogo/rtn-4 gene (Chen et al., 2000; GrandPré et al., 2000; Prinjha et al., 2000). Application of blocking antibodies (ABs) against the NogoA-specific region in spinal cord-lesioned mammals allows axon regeneration and to some extent reestablishment of function (Z'Graggen et al., 1998; Schwab, 2004) emphasizing its importance. Nogo-A has, in addition to its $\mathrm{N}$-terminal inhibitory NogoA-specific region (Chen et al., 2000), a second inhibitory and evolutionarily conserved stretch of amino acids, the Nogo-66 domain (Fournier et al., 2001) located within the C-terminal Reticulon Homology Domain (RHD) (Oertle et al., 2003a). Being evolutionarily conserved, homologs of the RHD- and Nogo66-domain were identified in fish RTN-4 (Diekmann et al., 2005). However, the inhibitory

\footnotetext{
Received July 23, 2009; revised 0ct. 15, 2009; accepted 0ct. 24, 2009.

This work was supported by grants from the Deutsche Forschungsgemeinschaft-DFG to CAOS and the Fonds der Chemischen Industrie. We thank Dr. Edward Malaga-Trillo for critical comments on the manuscript and generous support concerning technical issues, and Anette Y. Loos for zebrafish care.

*H.A., A.S., and G.P.S. contributed equally to this study.

Correspondence should be addressed to Claudia Stuermer, Universitaetstrasse 10, D-78457 Konstanz, Germany.

E-mail: Claudia.Stuermer@uni-konstanz.de.

DOI:10.1523/JNEUROSCI.3561-09.2009

Copyright $\odot 2009$ Society for Neuroscience ～0270-6474/09/2915489-10\$15.00/0
}

NogoA-specific region is absent from the zebrafish (ZF) $r$ tn-4 gene (Diekmann et al., 2005), and absence of this domain correlates with the unique ability of fish to regenerate CNS axons and restore function (Gaze, 1970). Interestingly, fish retinal ganglion cell (RGC) axons recognize rat CNS myelin-associated inhibitors (Bastmeyer et al., 1991) and collapse upon contact with the rat NogoA-derived peptide NIG $\Delta 20$ (Diekmann et al., 2005) suggesting that these axons possess a yet unknown receptor for the NogoA-specific domain. Aside from this Nogo-A receptor, fish RGC axons also express the GPI (glycosylphosphatidylinositol)anchored so-called Nogo-(66) receptor(s) NgR(s) (Fournier et al., 2001; Klinger et al., 2004). Mammalian NgRs are associated with other receptor proteins such as LINGO-1, p75, and/or TROY (Wang et al., 2002a; Mi et al., 2004; Park et al., 2005), which are-as demonstrated here-also present in the ZF genome. NgR binds Nogo-66 as well as other myelin proteins, such as OMGP (Wang et al., 2002b) and MAG (Domeniconi et al., 2002), and together with Nogo-66 they exert inhibition on axon growth through $\mathrm{NgRs}$ and coreceptors. This results in cofilin phosphorylation via Rock and the three gene products Lin-11, Isl-1, and Mec-3 (LIM) kinase and represents a second inhibition system for axon regeneration in mammals (Fournier et al., 2003; Hsieh et al., 2006; Yiu and He, 2006). Having Nogo-receptor(s) (Klinger et al., 2004), fish RGC axons are expected to respond to Nogo-66 from fish and perhaps to its mammalian counterpart which differ from one another in $21(\sim 30 \%)$ aa (Diekmann et al., 2005). If so, why then is regeneration successful in fish?

In the present study, we show that ZF-Nogo66 is growthpromoting whereas Rat-Nogo66 inhibits axon growth. These 
findings prompt the question, whether both Rat- and/or ZF-Nogo66 bind NgR, and whether enzymatic removal of GPIanchored proteins from the plasma membrane would reduce growth inhibition as well as growth permissiveness implying activation of different signal transduction pathways. Our results show that this is indeed so.

\section{Materials and Methods}

ZF were maintained in our breeding colony in the Tierforschungsanlage (TFA) of the University of Konstanz. The ZF optic nerve was transected in compliance with animal welfare legislation. Oligodendrocytes and myelin fractions from the ZF CNS were obtained from the injured optic nerve according to protocols published earlier (Bastmeyer et al., 1991, 1993).

Antibodies. The source of mouse monoclonal antibodies ( $\mathrm{mABs}$ ) was: $\mathrm{O} 4$ from Millipore, against GFAP from Sigma-Aldrich, against Neurolin from Zebrafish Information Network, and M802 against goldfish Thy-1 from our own laboratory (Deininger et al., 2003). Rabbit polyclonal antibodies (pABs) against cofilin, phospho-cofilin (Ser3) and phosphoErk1/2 (Thr202/Tyr204) were from Cell Signaling Technology, pAB against Myc (A-14) from Santa Cruz Biotechnology, goat pAB against GST from GE Healthcare GE Healthcare, anti-human $\mathrm{Fc}$ and secondary HRPcoupled pABs from Jackson ImmunoResearch and secondary Cy3- and Alexa-488-coupled pABs from Invitrogen.

Reverse transcriptase PCR. ZF gene expression of rtn-4 (isoform L), NgR, NgRH1a, and $\mathrm{NgRH} 2$ was analyzed in both the intact and lesioned optic nerve or retina between 2 and $10 \mathrm{~d}$ after nerve transection. Total RNA was prepared with the RNeasy Mini Prep Kit (Qiagen). First strand cDNA was synthesized under standard conditions with the Superscript FirstStrand synthesis System (Invitrogen), using an oligo (dT) primer. Zero transcripts (without Supertranscript II in the reaction) were performed in parallel to control for genomic DNA contamination in subsequent PCR. The amount and quality of different cDNA samples were evaluated by comparison with GAPDH.

Expression vectors and generation of fusion proteins. Constructs in pET28 expression vector encoding the Rat-NIG $\Delta 20$ and Rat-Nogo66 peptides were kindly provided by M. E. Schwab (University Zurich and ETH Zurich, Zurich,

Switzerland). ZF-Nogo66 sequence was derived from an adult ZF cDNA library and cloned in PCRII-TOPO vector (Invitrogen). Sequences were amplified by PCR, inserted into the pGEX-KG plasmid, and GST-fusion proteins were expressed in E. coli BL21-CodonPlus (DE3)-RIPL (Stratagene). Soluble GST-Rat-NIG $\Delta 20$ was purified using glutathioneSepharose 4B beads according to manufacturer's recommendations (GE Healthcare). GST-Rat-Nogo66 and GST-ZF-Nogo66 fusion proteins were purified from inclusion bodies according to GrandPré et al. (2000). For the expression of Nogo-EGFP-GPI fusion constructs, the RatNIG $\Delta 20$, Rat-Nogo66, and ZF-Nogo66 coding sequences were amplified by PCR and ligated into the pEGFP-ZF-PrP1-GPI eukaryotic expression vector (Málaga-Trillo et al., 2009). The mouse Myc-NgR1 expression Scale bars: $20 \mu \mathrm{m}$.
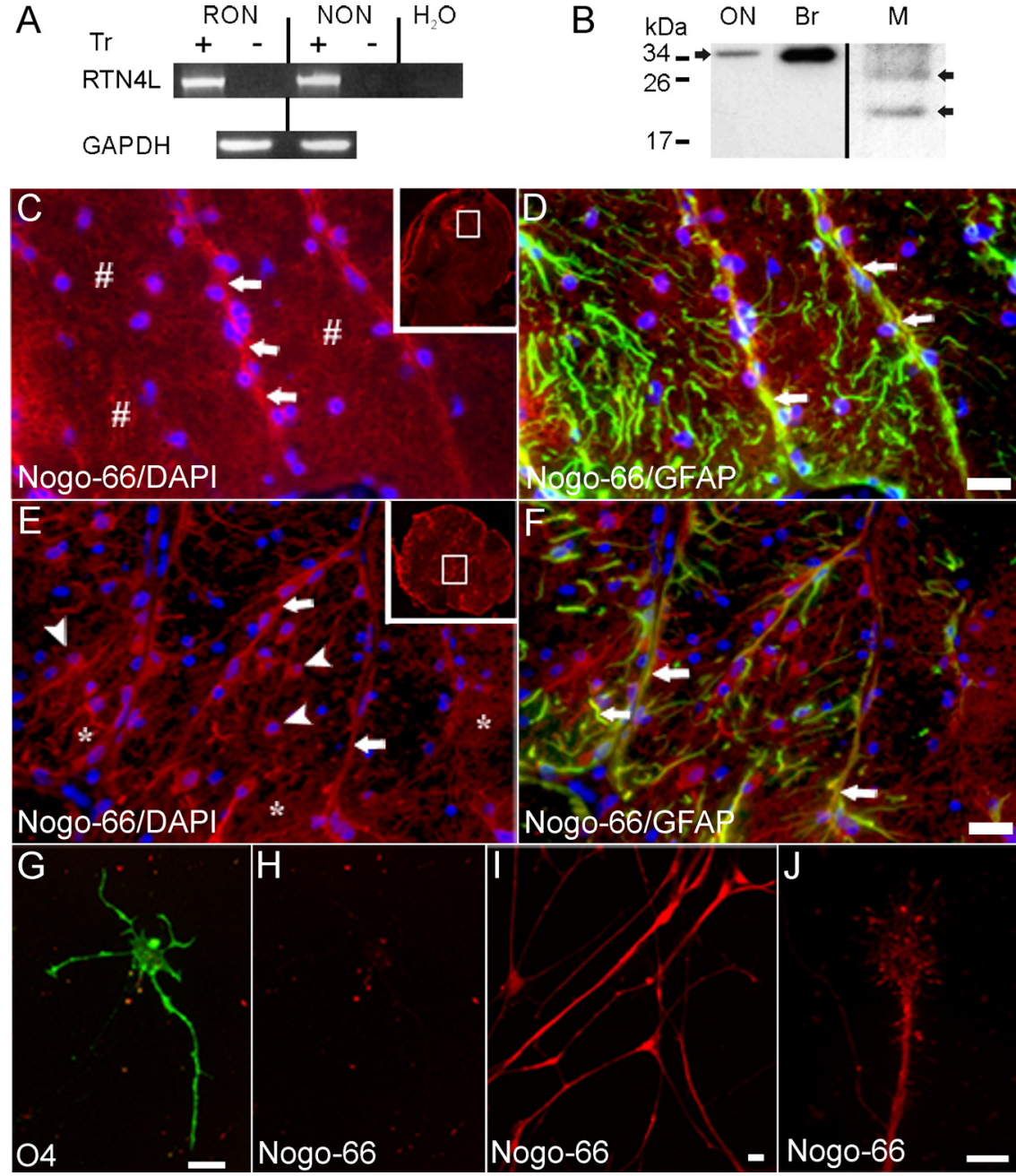

Figure 1. ZF-Nogo66 expression in the ZF CNS. A, RT-PCR analysis on normal (NON) and regenerating zebrafish optic nerves (RON) shows expression of ZF-RTN4L mRNA. A reverse transcriptase negative control ( $\mathrm{Tr}-$ ) was performed with each sample. RT-PCR with GAPDH-specific primers (GAPDH) served as a loading control in each reaction. $\boldsymbol{H}_{2} \mathrm{O}$, no template control. $\boldsymbol{B}$, Western $36 \mathrm{kDa}$ RTN4L in the optic nerve and brain, and 27 and $22 \mathrm{kDa}$ bands in CNS myelin. C, ZF-Nogo66 AB on cross sections of the unlesioned zebrafish optic nerve showed staining (red) across the entire nerve and was enriched in fascicle boundaries (arrows) magnification was derived. D, Same section as in C, showing GFAP-staining (green) in addition to Nogo66-staining (red) which colocalize at fascicle boundaries and GFAP-positive processes (arrows). $\boldsymbol{E}$, After optic nerve lesion, ZF-Nogo66 staining (red) was f which may represent oligodendrocytes (GFPA-negative; arrowheads). The insert shows the entire nerve and the region from ( Scale bars: $20 \mu \mathrm{m} . \mathbf{G}-\mathbf{I}$, Oligodendrocyte, isolated from the regenerating ZF optic nerve, is 04-positive (G, green) and $\mu \mathrm{m}$. J, Nogo-66 is associated with regenerating ZF RGC axons and growth cones after exposure to AB against ZF-Nogo66.

vector was kindly provided by S.M. Strittmatter (Yale University School of Medicine, New Haven, Connecticut). The ZF NgR sequence was amplified from an adult ZF cDNA library and cloned into the pCRII-TOPO vector (Invitrogen). The $\mathrm{ZF}-\mathrm{Myc}-\mathrm{NgR}$ plasmid was generated by replacing the mouse sequence from the Myc-NgR1 vector with the corresponding Myc-tagged fish NgR sequence (amino acids 27-479). For the generation of the mouse- and ZF-NgR(310)ecto-Fc fusion constructs, the mouse and fish ectodomains (aa 27-310) were amplified from the corresponding Myc-NgR plasmids and cloned into the pCRII-TOPO vector (Invitrogen). Then, both cDNAs were separately subcloned into the pIg-plus vector, upstream of the Fc sequence of the human IgG1 (Ott et al., 2001). The soluble control-Fc construct was 
generated by inserting the mouse prion protein leader sequence (amino acids 1-22) into the pIg-plus vector as described above.

Generation of the $P A B$ against ZF-Nogo66 and immunofluorescence. Rabbits were immunized with purified ZF-Nogo66 peptide after cleavage of the GST tag with Xa protease (Sigma-Aldrich). Cryostat sections (5-10 $\mu \mathrm{m})$ of the zebrafish optic nerve, normal and 4-5 d after optic nerve lesion, were immunostained using purified IgG fractions of $\mathrm{pAB}$ against ZF-Nogo66 and mAB against GFAP according to standard protocols (Ankerhold and Stuermer, 1999).

Immunostainings of cultured cells. HeLa cells were cultured, transfected and immunostained as previously described (Schrock et al., 2009). Briefly, HeLa cells were transfected on poly-lysine-coated coverslips for $24 \mathrm{~h}$, fixed, and stained under nonpermeabilizing conditions with antiMyc pAB and Alexa Fluor-568 Phalloidin (Invitrogen). For staining of live HeLa cells, cells were blocked in 1\% BSA in PBS at room temperature (RT) for 15 min, incubated in primary ABs against Rat- or ZF- Nogo peptides (ABs against Rat-Nogos were generously provided by M. E. Schwab) for $1 \mathrm{~h}$ at RT in PBS, washed and fixed in $4 \%$ PFA in PBS. Bound $\mathrm{ABs}$ were detected by secondary Cy3-coupled ABs. ZF glial cells in culture were stained live (as above) or after fixation and permeabilization with the pABs against ZF-Nogo66 and mAB O4 against a myelin/oligodendrocyte-specific ganglioside (Bastmeyer et al., 1991).

Western blots. Western blots with proteins from the ZF CNS (optic nerve, brain, CNS myelin) were performed according to standard protocols (Bastmeyer et al., 1991). Blots were incubated with the primary anti-ZF-Nogo66 AB for $2 \mathrm{~h}$ at RT, washed 3 times for $10 \mathrm{~min}$ in TBS-T, and developed with enhanced chemoluminescence and Hyperfilm TM (GE Healthcare).

Quantitative axon outgrowth assay. GST-ZF-Nogo66, GST-Rat-Nogo66, GST-Rat-NIG $\Delta 20$, and GST were applied at a concentration of $50 \mu \mathrm{M}$ to poly-lysine-coated coverslips for $12 \mathrm{~h}$ at $4^{\circ} \mathrm{C}$, and rinsed 3 times with cold L15 medium (Biochrom) before use. Isolated ZF retinae were prepared $4-9 \mathrm{~d}$ after optic nerve lesion and divided into $200 \times 200 \mu \mathrm{m}$ pieces with a tissue chopper (Vielmetter and Stuermer, 1989). Ten mini-explants were plated on each coverslip and incubated at $28^{\circ} \mathrm{C}$ in $\mathrm{F} 12$ medium (Invitrogen) supplemented with $1 \%$ fetal calf serum (FCS), $0.04 \%$ chicken serum, $2 \mathrm{~mm}$ L-glutamine, $0.025 \mathrm{M}$ HEPES, and antibiotics (10 $\mu \mathrm{g} / \mathrm{ml}$ streptomycin and $10 \mathrm{U} / \mathrm{ml}$ penicillin). After $24 \mathrm{~h}$, the number of axons growing from the retina miniexplants was determined in an inverted Axiovert 200M microscope (Zeiss) under phase contrast. Student's $t$ test was used for statistical analysis. The same axon outgrowth assay was performed under treatment of axons with $0.5 \mathrm{U} / \mathrm{ml}$ PI-PLC (Phosphatidylinositol-Phospholipase C, Sigma-Aldrich). Enzyme activity was controlled by immunostaining of the PI-PLC-treated axons after $24 \mathrm{~h}$ with the $\mathrm{mAB}$ against the GPI-anchored protein Thy- 1 .

Axon collapse assay with soluble ZF-Nogo66, Rat-Nogo66, or RatNIGA20. ZF axons from retina miniexplants were cultured on polylysine-coated coverslips in lumox petridishes (Greiner Bio-one) for $24 \mathrm{~h}$ at $28^{\circ} \mathrm{C}$. Femtotips of $0.5 \mu \mathrm{m}$ tip diameter connected to a microinjector (Femto Jet, Eppendorf) were loaded with either $100 \mu \mathrm{M}$ GST-ZFNogo66, GST-Rat-Nogo66, GST-NIG $\Delta 20$ or GST alone in elution buffer (PBS, $10 \mathrm{~mm}$ reduced Glutathione, $50 \mathrm{~mm}$ Tris, $\mathrm{pH}$ 8.0) supplemented with 1:20 phenol red. The tip was positioned at a distance of $50 \mu \mathrm{m}$ or $50-100 \mu \mathrm{m}$ from the individual growth cone by a micromanipulator (Inject Man NI 2, Eppendorf) under phase contrast. Each peptide was delivered continuously $(0.92 \mathrm{nl} / \mathrm{s})$ to the growth cone under injection pressure of $115 \mathrm{hPa}$. Time-lapse images were captured at $1 \mathrm{~min}$ intervals with an Axiovert 200M equipped with an AxioCam MRm camera, and edited using the Axiovision 4.7 software (all Zeiss). A test for axon growth was performed for $30 \mathrm{~min}$ without reagent release to assure that the selected growth cone advances well. Time-lapse images were collected for an average of $150 \mathrm{~min}$ and the behavior of the growth cone was classified as either "growing" (growth cone elongation) or "collapsing" (growth cone collapse). The Student's $t$ test was used for statistical analysis.

Contact assay: cocultures of ZF axons with Nogo peptide-expressing HeLa cells. HeLa cells transfected with different constructs encoding the EGFPcoupled Nogo-GPI fusion proteins and EGFP-GPI as control were plated on poly-lysine-coated coverslips for $12 \mathrm{~h}$. Cells were then transferred to

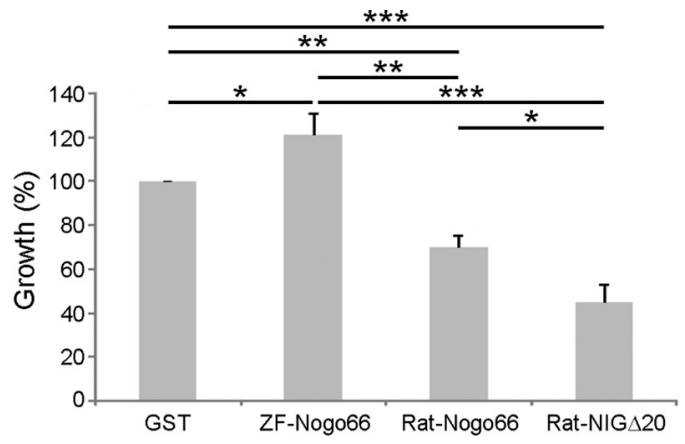

Figure 2. Axon outgrowth assay. Histogram showing the average number of ZF RGC axons per retina mini-explant after $24 \mathrm{~h}$ in culture. The quantification includes six separate experiments with a total number of $\sim 100$ retina mini-explants per substrate. Substrates are as indicated below each column. GST was used as a positive control for axon outgrowth. Bars in each column represent SEM, and asterisks indicate significant difference $\left({ }^{*} p<0.05 ;{ }^{* *} p<\right.$ $0.01 ;{ }^{* * *} p<0.001$ ) by Student's $t$ test. Number of axons per explant on ZF-Nogo66 is significantly higher compared to Rat-Nogo66 (and GST), and growth on Rat-Nogo66 is significantly higher compared to Rat-NIG $\Delta 20$.

F12 medium supplemented with $0.04 \%$ FCS, a condition which is appropriate for ZF cells and which allows survival and heterologous expression of HeLa cells in cross-species assays (Bastmeyer et al., 1991). Miniexplants were added and cocultured with HeLa cells at $28^{\circ} \mathrm{C}$. After $24 \mathrm{~h}$, the ZF growth cones were monitored when they contacted the transfected HeLa cells. Time-lapse images were captured at 1 min intervals for an average of $75 \mathrm{~min}$ as described above and the behavior of the growth cone was classified as either growing (growth cone elongates and grows across the cell) or collapsing (growth cone collapses after contact with the cell) or avoiding (growth cone avoids to cross the cell and grows around it) (Bastmeyer et al., 1991). The Student's $t$ test was used for statistical analysis.

Pull-down, PI-PLC, and cofilin phosphorylation assays. Mouse neuroblastoma (N2a) cells were cultured in MEM supplemented with $10 \%$ FCS, L-glutamine, and penicillin/streptomycin, and transfected with the mouse-, ZF-NgR(310)ecto-Fc, or control-Fc vectors using Lipofectamine 2000 (Invitrogen). After $24 \mathrm{~h}$ of transfection, cells were cultured in MEM supplemented with $20 \mathrm{~mm}$ sodium HEPES, pH 7.2, and $2 \%$ BSA for additional $24 \mathrm{~h}$. Then, conditioned media were collected, cleared by centrifugation at $15,000 \times g$ for $20 \mathrm{~min}$ at $4^{\circ} \mathrm{C}$, and $1 \mathrm{ml}$ aliquots were incubated with $10 \mu \mathrm{g}$ of purified GST, GST-Rat-Nogo66 or GST-ZF-Nogo66 for $1 \mathrm{~h}$ at $4^{\circ} \mathrm{C}$. Finally, all samples were incubated with $20 \mu \mathrm{l}$ of protein-G Sepharose (GE Healthcare) for $2 \mathrm{~h}$ at $4^{\circ} \mathrm{C}$, and bound proteins were analyzed by anti-GST and anti-Fc immunoblots. For PIPLC treatment, total membrane fraction of transfected N2a cells expressing the mouse or ZF Myc-NgR were prepared as previously described (Solis et al., 2007). Then, membrane fractions were treated with $0.5 \mathrm{U} / \mathrm{ml}$ PI-PLC in PBS for $3 \mathrm{~h}$ at $25^{\circ} \mathrm{C}$, centrifuged at $100,000 \times g$ for $45 \mathrm{~min}$ at $4^{\circ} \mathrm{C}$, and soluble fractions were analyzed by an anti-Myc immunoblot. For analysis of cofilin phosphorylation, transfected and non-transfected N2a cells were starved overnight and stimulated with $50 \mathrm{~nm}$ purified GST, GST-Rat-Nogo66 or GST-ZF-Nogo66 in MEM for $30 \mathrm{~min}$ at $37^{\circ} \mathrm{C}$. Cell lysates were prepared as previously described (Munderloh et al., 2009) and analyzed by Western blots with anti-cofilin, anti-phospho-cofilin, and anti-phospho-Erk1/2.

Neurite outgrowth assays with hippocampal neurons. Hippocampal neurons were prepared from 1- to 3-d-old mice on poly-lysine-coated coverslips as previously described (Munderloh et al., 2009). For the quantification of neurite outgrowth, neurons received $10 \mu \mathrm{g} / \mathrm{ml} \mathrm{GST-}$ ZF-Nogo66 and/or GST-Rat-Nogo66 or GST, applied immediately after plating together with or without $0.5 \mathrm{U} / \mathrm{ml}$ PI-PLC, and fixed $24 \mathrm{~h}$ later. Neurites of isolated neurons were traced, and their length was measured using ImageJ software (National Institutes of Health). Since the length of the longest neurites always correlated with length of all neurites, only one parameter, namely the length of the longest neurite, was documented in the figures. 
Sequence alignments. GenBank accession numbers of protein sequences used for multiple alignments are listed in supplemental Table 1, available at www.jneurosci.org as supplemental material. Sequences were aligned using MUSCLE (Edgar, 2004) and edited manually. Alignment annotation was done in Jalview (Waterhouse et al., 2009) and secondary structure annotation of Nogo-66 alignment by Robetta (Chivian et al., 2005). Secondary structure annotation of $\mathrm{NgR}$ was performed based on Pfam (Finn et al., 2008), UniProt (Jain et al., 2009), and SMART (Letunic et al., 2006) feature data.

\section{Results}

Expression of ZF-RTN4/Nogo66 in the regenerating $\mathrm{ZF}$ optic nerve/tract

The expression of RTN-4 and its Nogo-66 domain in the fish optic nerve - a precondition for affecting ZF RGC axon growth and regeneration - was analyzed by reverse transcriptase PCR (RT-PCR) showing RTN-4L (the largest of the splice variants RTN4-L, -M and -N; Diekmann et al., 2005) in the normal and regenerating optic nerve (Fig. 1A). Western blots with anti-ZF-Nogo66 AB revealed bands at $36 \mathrm{kDa}$ in the optic nerve, isolated glial cells and brain corresponding to RTN-4L, and at 27 and $22 \mathrm{kDa}$ [RTN4-M and -N, respectively (Diekmann et al., 2005)] in fractions highly enriched in optic nerve myelin (Fig. 1B). ZF-Nogo66 AB gave staining of axon bundles and glial cells which were coimmunostained by the respective glia-markers (Fig. $1 C-I$ ).

In the regenerating optic nerve, Nogo-66 $\mathrm{AB}$ staining detected GFAP-positive processes of astrocytes, GFAP-negative Nogo66positive cells resembling oligodendrocytes (Fig. $1 C-F$ ) and O4-positive fish oligodendrocytes in vitro (Fig. $1 G-I$ ) but was not detected on the cell surface when ABstaining was performed on live cells. Labeling of fixed cells, however, resulted in intense intracellular staining which is consistent with results obtained in mammals where Nogo-A shows association with the ER and is surface-exposed in very small amounts (Dodd et al., 2005). Irregular patches and diffuse features (Fig. $1 E$ ) most likely representing myelin debris (Strobel and Stuermer, 1994; Ankerhold and Stuermer, 1999) as well as ZF RGC axons in the nerve and in vitro were also Nogo66-positive (Fig. 1C,J). Thus, regenerating axons in the optic nerve could encounter Nogo-66 associated with myelin debris and other axons.

\section{Quantitative outgrowth assay: ZF-Nogo66 is growth-permissive}

To clarify whether ZF-Nogo66 has inhibitory properties like its mammalian ortholog, number of axons from retina miniexplants cones.
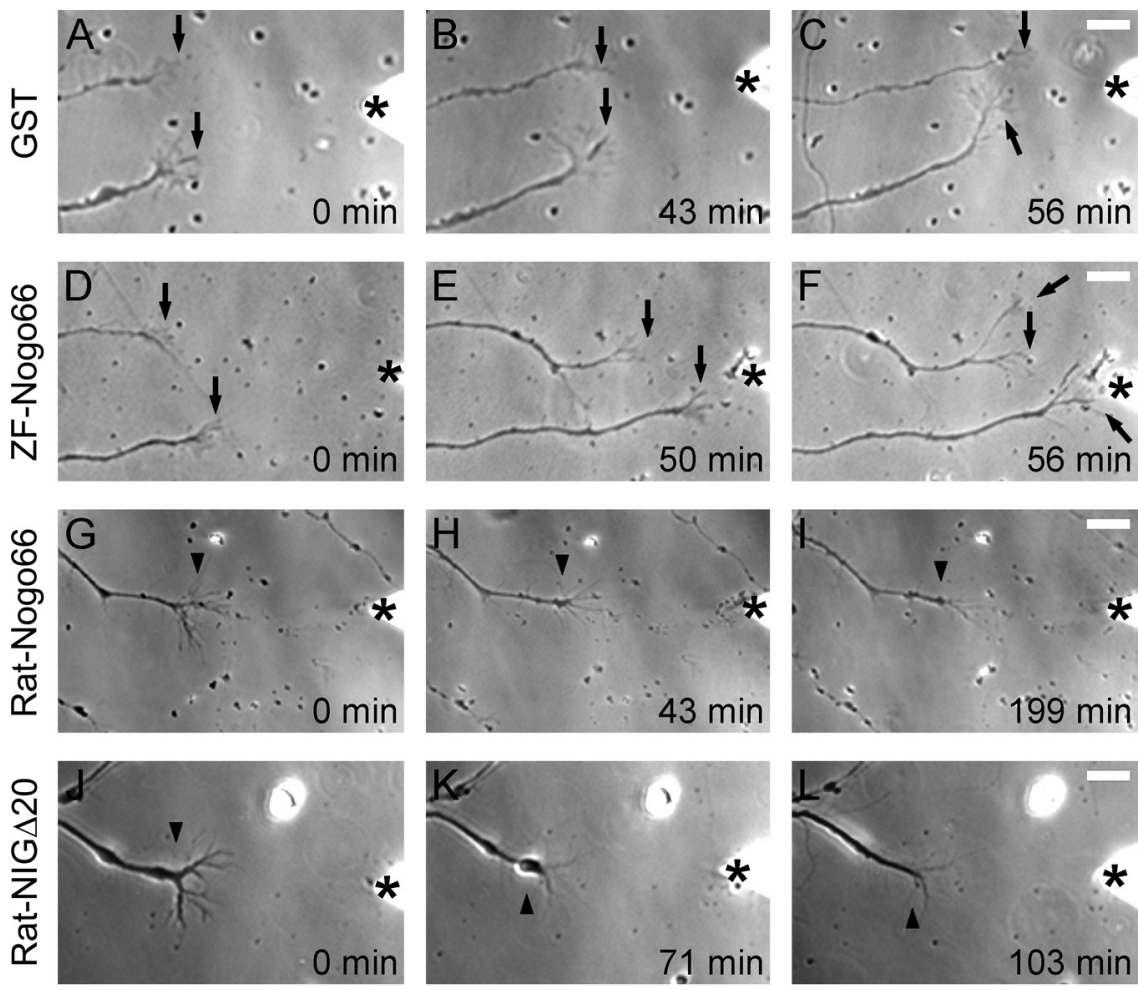

$\mathrm{M}$

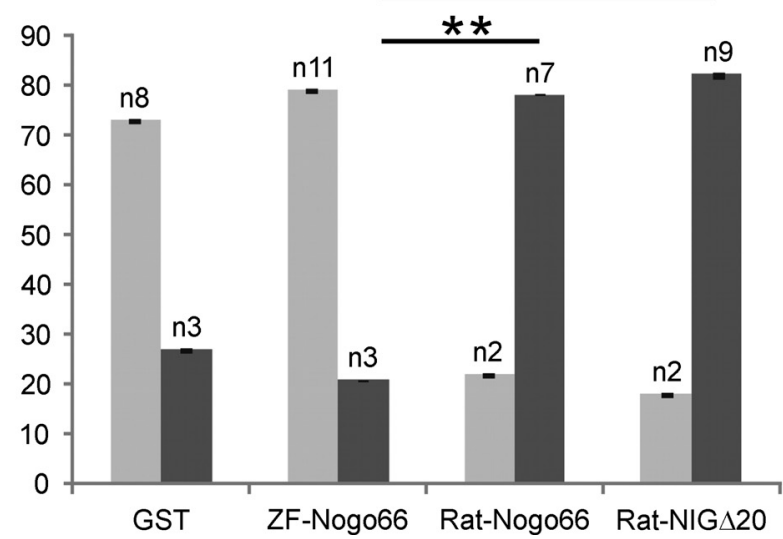

\section{\% Growth \\ \% Collapse}

Figure 3. Collapse assay. $\boldsymbol{A}-\boldsymbol{L}$, Time-lapse microscopy of ZF RGC growth cones responding to GST alone (A-C), to GST-ZFNogo66 (D-F), GST-Rat-Nogo66 (G-I), and GST-Rat-NIG $\Delta 20(\boldsymbol{J}-\boldsymbol{L})$. Time of application in minutes is indicated. The position of the femtotip is marked by an asterisk $\left({ }^{*}\right)$. $\boldsymbol{A}-\boldsymbol{F}$, The growth cones (arrows) elongate after application of soluble GST $(\boldsymbol{A}-\boldsymbol{C})$ or GST-ZF-Nogo66 (D-F). G-L, Cessation of growth cone motility after application of Rat-GST-Nogo66 (G-I) or Rat-GST-NIG $\Delta 20$ $(\boldsymbol{J}-\boldsymbol{L})$. Arrowheads indicate retraction bulbs of collapsed growth cones. Note the contact between the lower of the two growth cones $\left(\boldsymbol{F}\right.$, arrow) and the tip of the needle $\left(^{*}\right)$. Scale bar: $10 \mu \mathrm{m}$. $\boldsymbol{M}$, Quantification of growth cone responses: growth (gray bars), collapse (black bars) following application of GST-ZF-Nog066, GST-Rat-Nog066, GST-Rat-NIG $\Delta 20$ and GST. Bar in columns, SEM; $n$ is the number of growth cones. A statistical difference exists between all experiments but only the two most important ones are indicated by asterisks ( ${ }^{*} p<0.05 ;{ }^{* *} p<0.01$ according to Student's $t$ test). Note that ZF-Nogo66 allows a significantly higher percentage of growth as opposed to Rat-Nogo66 and Rat-NIG $\Delta 20$ which cause collapse in 79 and $82 \%$, respectively, of the growth

in dependence of the substrate was determined in the "quantitative outgrowth assay" (Vielmetter and Stuermer, 1989). From six independent experiments including $\sim 100$ retinal explants for each substrate, axon growth on recombinant GST-ZF-Nogo66 or GST-Rat-Nogo66 was evaluated. This value was compared to the number of axons on the inhibitory substrate GST-RatNIG $\Delta 20$ (Oertle et al., 2003b), which served as "inhibition control" (Diekmann et al., 2005) and axon numbers on GST $(100 \%)$ as "growth control" (Fig. 2). The average number of 

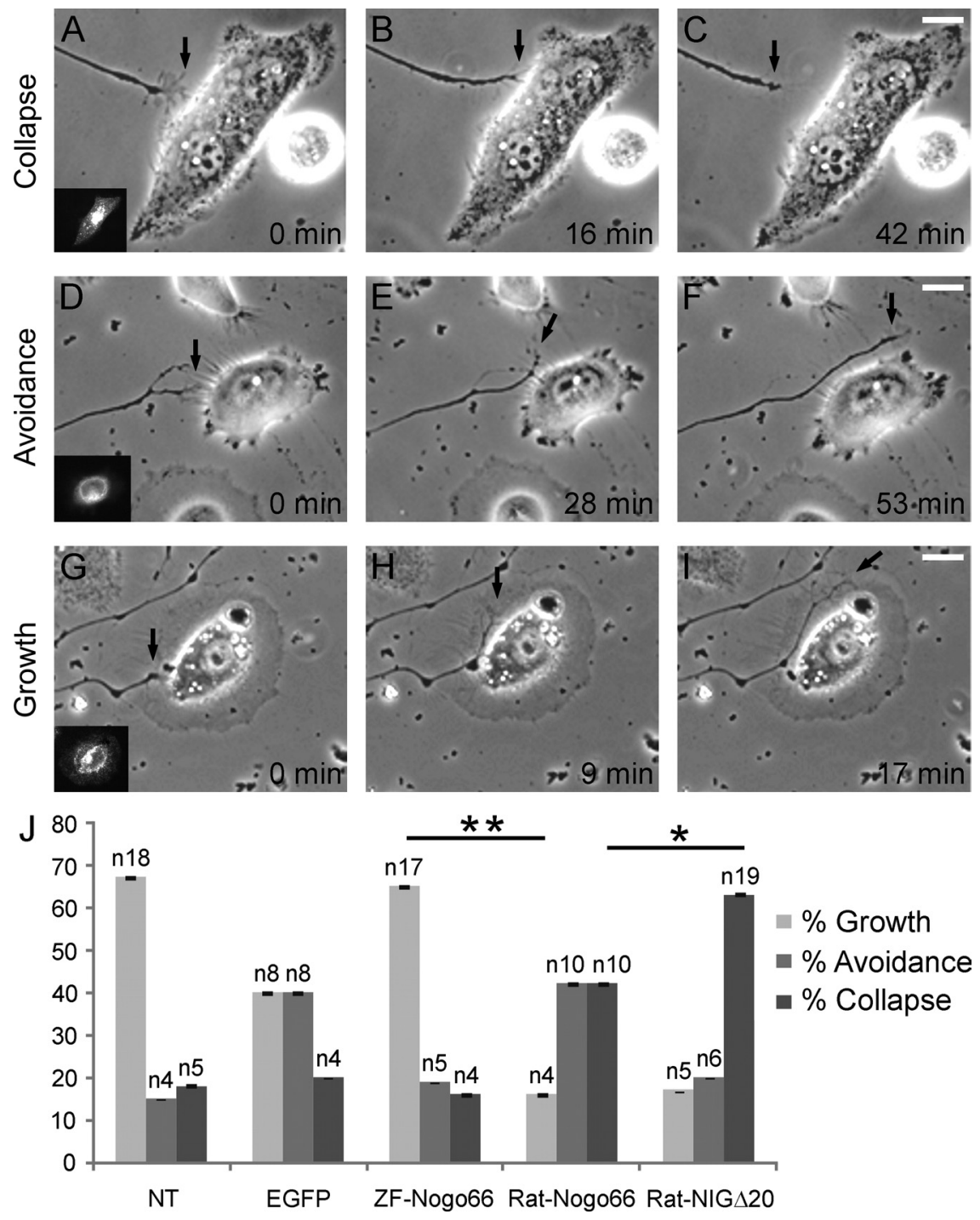

Figure 4. Contact assay. ZF RGC axons were cocultured with non- (NT) or transfected HeLa cells expressing ZF-Nogo66-EGFPGPI, Rat-Nog066-EGFP-GPI, Rat-NIG $\Delta$ 20-EGFP-GPI, or EGFP-GPI (insert). A-I, Growth cone (arrows) contact with cells resulted in growth cone collapse $(\boldsymbol{A}-\boldsymbol{C})$, avoidance $(\boldsymbol{D}-\boldsymbol{F})$ and growth on the cell $(\boldsymbol{G}-\boldsymbol{I})$. Scale bar, $20 \mu \mathrm{m}$. J, Quantification of the growth cone responses in dependence of the expressed Nogo peptide. All differences between substrates are significant but only the two most important ones are labeled accordingly $\left({ }^{*} p<0.05 ;{ }^{* *} p<0.01\right.$ according to Student's $t$ test). Bar in columns, SEM; $n$, number of growth cones.

axons on Rat-Nogo66 with 19 axons/explant was significantly reduced compared to the controls (GST) showing an average of 27 axons/explant whereas the number of axons on Rat-NIG $\Delta 20$ with 12 axons/explant was significantly lower than on RatNogo66 (Fig. 2). ZF-Nogo66, however, had no inhibitory effect on growing axons: the number of axons (33 axons/explant) was significantly higher than on the control substrate GST and $\sim 2.7$ and 1.7 times higher than on Rat-NIG $\Delta 20$ and Rat-Nogo66, respectively. Thus, ZF-Nogo66 appears to be a better substrate than GST for axon growth. This contrasts to the properties of RatNogo66 which negatively affects the growth of fish axons.

\section{Collapse assay: ZF-Nogo66 allows growth cone elongation}

Whether Rat-Nogo66 but not ZF-Nogo66 might cause collapse was determined by time-lapse microscopy and the reaction of RGC growth cones upon application of GST-ZF-Nogo66, GSTRat-Nogo66, GST-Rat-NIG $\Delta 20$ and GST at a distance of $50 \mu \mathrm{m}$ (and 50-100 $\mu \mathrm{m}$; supplemental Fig. 1, available at www.jneurosci. org as supplemental material) to the growth cone, over an average time of 150 min (Fig. 3). GST control protein application did not affect extension or motility (Fig. $3 A-C$ ) in $73 \%$ of the tested growth cones. Twenty-seven percent collapsed which we consider as the "background collapse rate," which was observed earlier in such assays with fish RGCs and rat dorsal root ganglion neurons and goldfish CNS myelin (Wanner et al., 1995). Here, with GST-ZF-Nogo66, 79\% of growth cones continued to grow (Fig. 3D-F,M) and $21 \%$ collapsed suggesting that ZFNogo66 has no collapsing activity beyond the background rate. One growth cone (Fig. $3 F$ ) grew toward the source of ZFNogo66 and established intimate contact with the tip of the micropipette-a behavior not seen with the other peptides. In contrast, GST-Rat-Nogo66 and GSTNIG $\Delta 20$ induced collapse in 78 and $82 \%$ of growth cones, respectively (Fig. 3G-I, $J-M)$. Thus, the percentage of elongating growth cones during the application of GST-ZF-Nogo66 was three to four times higher than with GST-Rat-Nogo66 (22\%) or GST-Rat-NIG $\Delta 20$ (18\%) which caused collapse of the vast majority of growth cones. These findings show that RatNogo66 has an inhibitory influence on fish axon growth whereas ZF-Nogo66 does not impair growth cone advance (beyond the background collapse rate) and hence is growth permissive.

\section{Contact assay: axons contacting HeLa cells expressing Rat- and ZF-Nogo66, respectively}

To analyze whether Nogo-66 and NIG $\Delta 20$ affect RGC growth cones when exposed on the surface of cells, we fused the relevant peptides to a GPI-anchor from ZF Prion protein-1 and EGFP (Málaga-Trillo et al., 2009) for the transfection of HeLa cells (rather than primary fish oligodendrocytes - which we would have preferred for these experiments but which gave a smaller than 1\% transfection rate) and used EGFP-GPI transfected HeLa cells as control. HeLa cells expressing NIG $\Delta 20$ EGFP-GPI on the surface (supplemental Fig. 2, available at www. jneurosci.org as supplemental material) caused collapse in $63 \%$ and avoidance in $20 \%$ of the growth cones, and $17 \%$ crossed the cells (Fig. 4). HeLa cells expressing ZF-Nogo66-EGFP-GPI showed the opposite: $16 \%$ collapse, 19\% avoidance, and $65 \%$ growth across the cells. Rat-Nogo66-EGFP-GPI gave $42 \%$ collapse and $42 \%$ avoidance, and only $16 \%$ crossed the cells. Thus, ZF-Nogo66 allows four times more cell crossings than RatNogo66 and NIG $\Delta 20$. In contact with non-transfected cells, growth cone collapse and avoidance occurred in 18 and 15\%, respectively, and $67 \%$ crossed untransfected cells, ratios similar to ZF-Nogo66. EGFP-GPI control transfected cells provoked collapse in 20\%, avoidance in $40 \%$ and growth across in $40 \%$ (Fig. 4). Why EGFP-GPI-expressing cells caused an increase in avoid- 

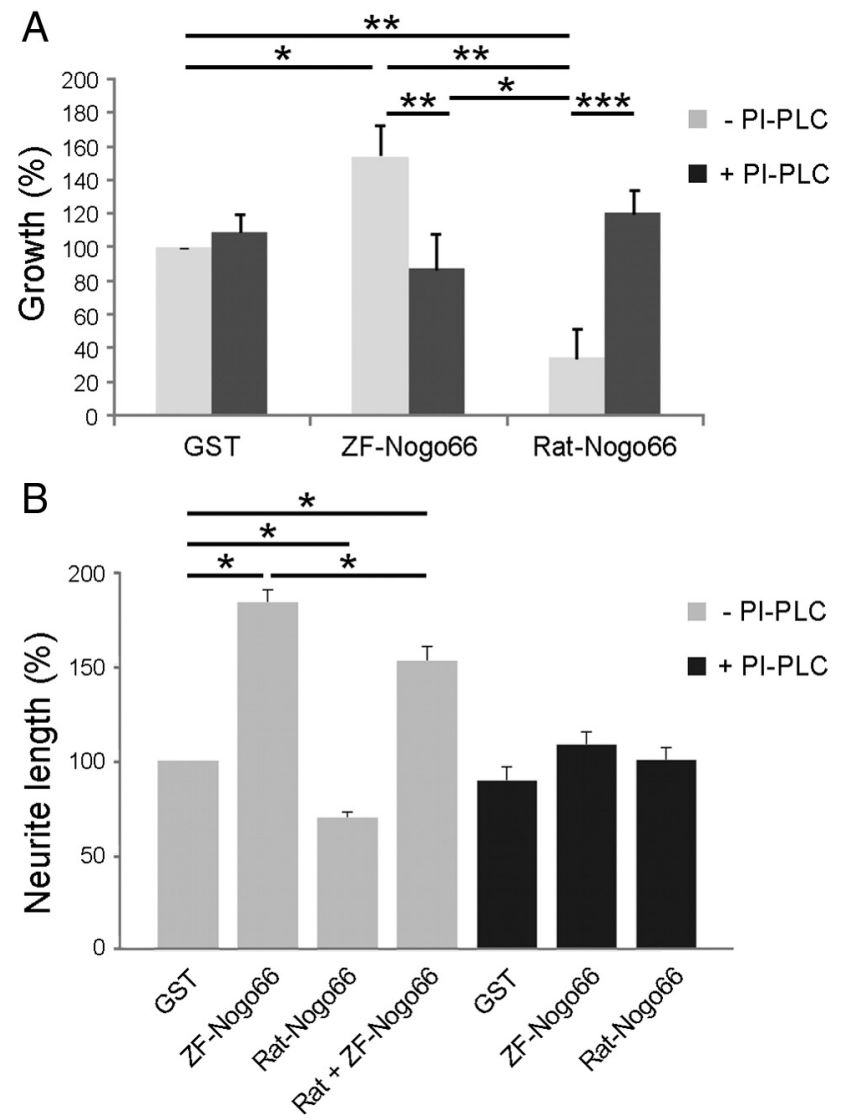

Figure 5. Axon/neurite growth assay under PI-PLC. $A$, ZF RGC axons were grown on GST (control), ZF- or Rat-Nogo66 in the presence of PI-PLC. The number of axons from ZF retinal explants growing on Rat-Nogo66 in the presence of PI-PLC increases significantly but decreases significantly on ZF-Nogo66 under these conditions whereas there is no change of axon number on GST. $\boldsymbol{B}$, Mouse hippocampal neurons extend significantly longer neurites when ZF-Nogo66 is added to the culture but have significantly shorter neurites with Rat-Nog066, both values in comparison to GST. In the presence of PI-PLC, the gain in neurite length on ZF-Nogo66 is lost (significant) and the reduction in length by Rat-Nogo66 is decreased (significant). Bar in columns, SEM ${ }^{*} p<0.05 ;{ }^{* *} p<0.01$ according to Student's $t$ test.

ance cannot be readily explained but puts even more weight on the lower avoidance rate caused by the ZF-Nogo66 fusion protein and underscores its permissiveness. Thus, ZF growth cones collapse in contact with Rat-Nogo66 and Rat-NIG $\Delta 20$, whereas ZFNogo66 had no collapsing activity beyond the background rate also seen with untransfected cells and EGFP-GPI.

\section{Rat-Nogo66 inhibits ZF axon growth probably via NgR}

To determine whether the inhibition of Rat-Nogo66 on ZF RGC axons involves fish $\mathrm{NgR}$, we confirmed its expression in $\mathrm{ZF}$ retina by RT-PCR (supplemental Fig. 3, available at www.jneurosci.org as supplemental material), and performed a quantitative outgrowth assay using PI-PLC to remove GPI-anchored proteins, including $\mathrm{NgR}$, from the surface. The enzymatic activity of PIPLC was confirmed by immunostaining with ABs against a GPI-anchored protein of ZF RGC axons (supplemental Fig. 3, available at www.jneurosci.org as supplemental material). With Rat-Nogo66 as substrate and in presence of PI-PLC, the number of axons raised to $121 \%$ over GST control (100\%), and declined to $35 \%$ in the absence of PI-PLC (Fig. $5 A$ ). Growth of PI-PLCtreated axons on Rat-Nogo66 was statistically different from the GST control meaning that Rat-Nogo66 transmits signals via a GPI-anchored receptor, most likely ZF-NgR. Moreover, growth on ZF-Nogo66 without PI-PLC treatment (154\%) was statistically different from the growth on the GST control (Fig. 5A), suggesting that ZF-Nogo66 has indeed growth-permissive/ growth-promoting properties. If so, would the growth of mammalian neurons also be enhanced by ZF-Nogo66 — via NgR?

\section{Zebrafish Nogo-66 stimulates neurite outgrowth in mouse hippocampal neurons probably via $\mathrm{NgR}$}

ZF-Nogo66 and/or Rat-Nogo66 were added to the medium of cultured mouse hippocampal neurons (Fig. 5B). Surprisingly, ZF-Nogo66 significantly increased neurite outgrowth over control (GST) by $84 \%$. However, application of Rat-Nogo66 inhibited neurite outgrowth by $\sim 30 \%$. Moreover, when Rat and ZF-Nogo66 were added together, the ZF-Nogo66-dependent increase in neurite outgrowth was significantly reduced by $17 \%$, indicating that ZF-Nogo66 and Rat-Nogo66 might act via the same receptor.

Whether these opposite Nogo-66 effects on neurite growth might be transmitted by GPI-linked receptors including NgR was addressed by application of PI-PLC to hippocampal neurons which were treated with Rat- or ZF-Nogo66. Both, ZF-Nogo66 (positive) and Rat-Nogo66-mediated (negative) effects were abolished by PI-PLC (Fig. 5B), indicating that both ligands bind to GPI-linked receptors (including $\mathrm{NgR}$ ).

\section{Rat- and ZF-Nogo66 bind to the same NgR}

Sequence alignments (supplemental Fig. 4, available at www. jneurosci.org as supplemental material) indicate that Nogo-66, $\mathrm{NgR}$ and, in particular, the NgR ligand-binding region (GrandPré et al., 2002; He at al., 2003; Schimmele and Plueckthün, 2005; Li et al., 2006) of fish and mammals are homologous suggesting that Nogo66-evoked signaling through NgR could theoretically proceed in fish in the same way as in mammals. These considerations imply that ZF- as well as Rat-Nogo66 interacts with ZF$\mathrm{NgR}$ as well as with mouse $\mathrm{NgR}$. The opposite reaction to binding of different Nogos to NgR can, therefore, only be explained if ZFand Rat-Nogo66 activate different signal transduction pathways.

To clarify whether this is the case we had to first determine directly (biochemically) Nogo-66 binding to NgR. We cloned the ZF homolog of mammalian NgR (Fournier et al., 2001; Klinger et al., 2004) and transfected HeLa and N2a cells with the Myctagged mouse- and ZF-NgRs. Immunostaining of transfected HeLa and N2a cells showed that the ZF-Myc-NgR construct is expressed at the plasma membrane in a comparable manner as the mouse Myc-NgR (supplemental Fig. 5A,B). Moreover, membranes prepared from Myc-NgR-expressing N2a cells and exposed to PI-PLC had, according to results of Western blots, lost the proteins which were in the soluble pool instead (supplemental Fig. 5C, available at www.jneurosci.org as supplemental material). For Nogo66-binding assays, we generated soluble mouseand ZF-NgRs consisting of the so-called NgR ectodomain (aa 27-310; NgR(310)ecto) fused to the human IgG1 Fc domain $(\mathrm{NgR}(310)-\mathrm{Fc})$ which allows to examine receptor-ligand interaction in pull-down assays. Soluble Fc served as control (supplemental Fig. 5D, available at www.jneurosci.org as supplemental material). Indeed, mouse-NgR coprecipitated not only RatNogo66 but also ZF-Nogo66 (Fig. 6A), and ZF-NgR coprecipitated Rat- and ZF-Nogo66 (Fig. 6A). These data are consistent with the high degree of homology between the fish and Rat proteins, and suggest that ZF-Nogo66 which is not inhibitory, binds ZF-NgR, and that Rat-Nogo66 which does inhibit ZF axon growth, also binds to ZF-NgR. 


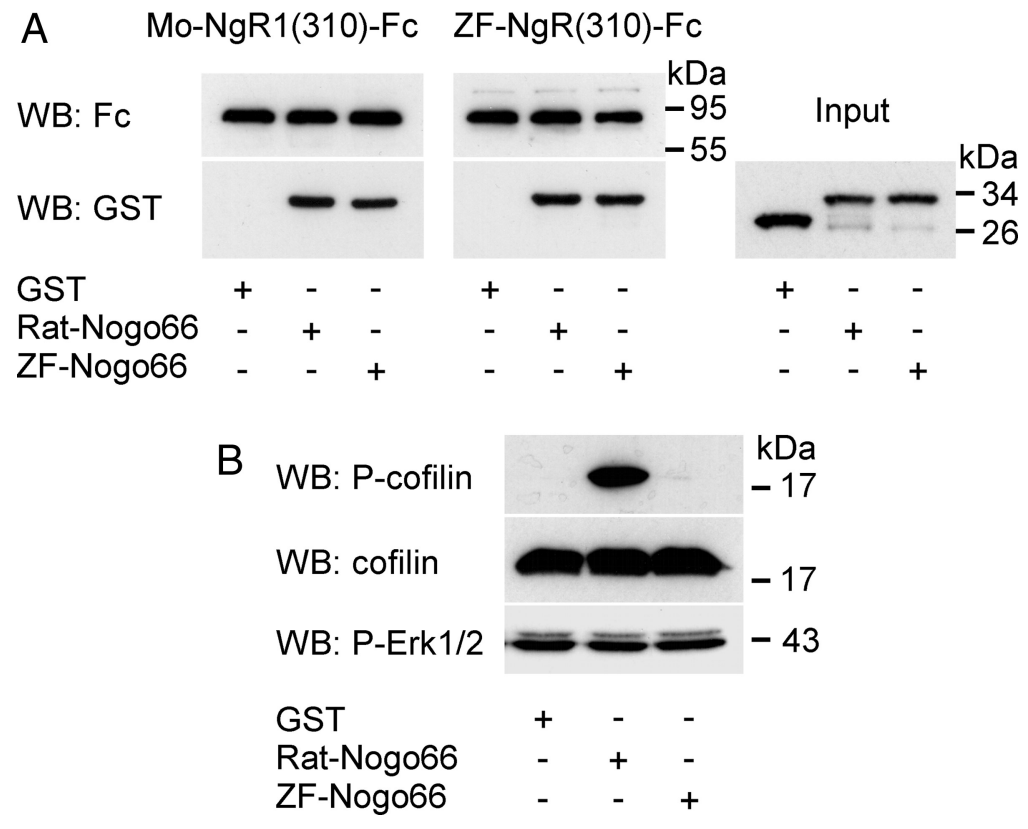

Figure 6. Nogo66-NgR binding assays and cofilin phosphorylation by ZF-Nogo66. A, Conditioned media from N2a cells expressing the soluble mouse- or ZF-NgR-Fc constructs (Mo-NgR1(310)-Fc and ZF-NgR(310)-Fc, respectively) were incubated with purified GST, GST-Rat-Nogo66 or GST-ZF-Nogo66 (Input). After precipitation, the mixtures were exposed to ABs against Fc and GST for detection of interacting proteins by Western blots (WB). Note that soluble mouse- and ZF-NgRs interact with both Rat- and ZF-Nogo66 but not with GST. $\boldsymbol{B}$, N2a cells were treated with GST, GST-Rat-Nogo66 or GST-ZF-Nogo66 and the corresponding cell extracts were analyzed by WB with ABs against cofilin, phosphorylated-cofilin (P-cofilin), and phosphorylated-Erk1/2 (P-Erk1/2). Treatment with Rat-Nogo66 strongly increased the phosphorylation of cofilin (P-cofilin), whereas ZF-Nogo66 showed no effect. Activation of Erk1/2 was not affected by Rat- or ZF-Nogo66 treatment.

Rat-Nogo66 but not ZF-Nogo66 triggers activation of cofilin Nogo66-NgR-dependent inhibition involves the signaling from Rho via ROCK and LIMK to cofilin (Hsieh et al., 2006) and $\mathrm{Ca}^{2+}$-dependent EGFR (epidermal growth factor receptor) signaling to Erk1/2 (Koprivica et al., 2005) both affecting cytoskeletal dynamics. Therefore, we analyzed the phosphorylation state of cofilin and Erk1/2 after treatment of N2a cells and hippocampal neurons with Rat- and ZF-Nogo66. In N2a cells, exposed to Rat-Nogo66, cofilin was heavily phosphorylated whereas Erk1/2 was not (Fig. 6 B; supplemental Fig. 6, available at www.jneurosci. org as supplemental material). However, ZF-Nogo66 did not provoke phosphorylation of cofilin or of Erk1/2 (Fig. 6B). Moreover, expression of ZF-NgR in N2a cells did not lead to notable changes in the state of cofilin phosphorylation by ZF-Nogo66 treatment (supplemental Fig. 6, available at www.jneurosci.org as supplemental material). Likewise, cofilin was not phosphorylated to any significant extent in mouse hippocampal neurons exposed to ZF-Nogo66 whereas Rat-Nogo66 did cause cofilin phosphorylation (data not shown). Together, our data indicate that ZFand Rat-Nogo66 can bind to both, NgR from the mouse and NgR from the fish, but ZF-Nogo66-NgR interaction seems not to activate the pathway that is prevalent with Rat-Nogo66 and that leads to cofilin phosphorylation and blockage of axon growth/ neurite extension. In other words, no axon growth inhibition by ZF-Nogo66!

\section{Discussion}

The present results have uncovered new factors underlying successful axon regeneration in the fish CNS: Binding of Nogo-66 of fish RTN-4 to NgR has no inhibitory effect on fish RGC axon growth or on mammalian hippocampal neurons and is, instead, growth promoting whereas Rat-Nogo66 on the same receptors, however, blocks growth. Thus, ZF- and Rat-Nogo66 apparently exert opposite effects via the same receptor. The involvement of $\mathrm{NgR}$ in the transmission of both inhibition and growth support was suggested by the outcome of assays with PIPLC to remove the GPI-anchored Nogo66 receptors and biochemical assays, confirming that Rat- as well as ZF-Nogo66 directly bind to the mouse- and to the $\mathrm{ZF}$ $\mathrm{NgR}$. Sequence alignments suggest that ZF- and Rat-Nogo66 can even use the same ligand binding sites of the NgRs. However, Rat-Nogo66 elicits a signal transduction cascade culminating in the phosphorylation of cofilin and arrest of axon growth, whereas ZF-Nogo66 binding to ZF- or mouse-NgR has no influence on cofilin phosphorylation and promotes axon growth. This implies that nonconserved residues of Rat- and ZF-Nogo66 in and/or outside the predicted ligandbinding site of NgRs are responsible for the transmission of opposite downstream signals.

Cofilin effects actin depolymerization when activated (dephosphorylated) which is required for actin cytoskeleton dynamics during growth cone elongation (Meberg and Bamburg, 2000; Endo et al., 2007). Cofilin phosphorylation interferes with actin dynamics resulting in growth inhibition and collapse (Niederöst et al., 2002; Hsieh et al., 2006) as seen with Rat-Nogo66 and NIG $\Delta 20$. The phosphorylation state of cofilin was not affected by ZF-Nogo66 implying it remains active-probably together with other actin modifying proteins promoting axon/neurite elongation which are regulated by ZF-Nogo66.

\section{Comparison of growth inhibition in mammals and fish}

The Nogo-66 effects on cofilin were determined in N2a cells, a well growing neuronal cell line allowing efficient transfection and biochemical assays. Results in the same direction were obtained with primary hippocampal neurons showing increased neurite growth with ZF-Nogo66 and a decrease with Rat-Nogo66. The outcome of these experiments was entirely compatible with the growth cone responses using ZF RGC axons.

With NIG $\Delta 20$ and Rat-Nogo66, respectively, collapse occurred in $82 \%$ and $79 \%$ of the growth cones as opposed to $79 \%$ growth with ZF-Nogo66. Likewise, with Rat-Nogo66-expressing cells, avoidance (42\%) and collapse (42\%) amounted to $84 \%$, whereas long-lasting exploratory growth and crossing occurred in $65 \%$ of the growth cones in contact with ZF-Nogo66expressing cells. NIG $\Delta 20$-expressing cells blocked growth in $83 \%$ of the growth cones but caused more growth cones collapse (63\%) than Rat-Nogo66 (42\%), suggesting that Nogo-A is a stronger growth inhibitor than Rat Nogo-66, at least for ZF RGC axons. The present results suggest that absence of the Nogo-Aspecific inhibitory domain and the transition of Nogo66dependent signal transduction pathways from inhibition to growth-promotion correlates with and seems to be causally linked to the success of axon regeneration in fish. 


\section{Nogo-66 receptors}

The theoretical and biochemical analyses of Nogo-66 interaction with NgR imply that ZF- and Rat-Nogo-66 bind equally well to the predicted ligand-binding site of the $\mathrm{NgRs}$ (He et al., 2003; Barton et al., 2003). This is no proof that ligands bind as predicted but the probability is high insofar as the ligand-binding region of the receptor was identified by Laurén et al. (2007), was experimentally mapped in the human proteins (Schimmele and Plückthun, 2005), and is highly conserved in zebrafish. This is compatible with the present results showing that one and the same axon/neurite recognizes ZF- and Rat-Nogo66. A plausible explanation for the opposite signals through $\mathrm{NgR}$ in dependence of the ligands has to be sought in amino acid exchanges in the predicted binding region (amino acid Ser25 to Glu31; helix 2, supplemental Fig. 4, available at www.jneurosci.org as supplemental material) of the Rat- as opposed to the ZF-Nogo66 (amino acid Lys25 to Ala31, helix 2), which, when interacting with $\mathrm{NgR}$, may cause different conformational changes when from fish rather than mammal. This leads to the speculation that the recruitment of a different set of $\mathrm{NgR}$ coreceptors and/or switch in the preference of membrane domains may underlie inverse signaling. In other words, since Rat-Nogo66 leads to the recruitment of the coreceptors LINGO-1, p75, and/or TROY in mammals (Wang et al., 2002a; Mi et al., 2004; Park et al., 2005), Rat-Nogo66 binding to ZF-NgR should also recruit LINGO-1, $\mathrm{p} 75$, and/or TROY in fish resulting in cofilin phosphorylation and growth inhibition. ZF-Nogo66 binding to NgR in mammals and fish should abrogate recruitment of this coreceptor set and either call in another set of coreceptors or cause a transition into different membrane microdomains with access to signaling pathways involved in growth promotion. Since $\mathrm{NgR}$ is a GPI-anchored receptor, it might transit into specific microdomains ("lipid rafts") upon ZF-Nogo66 binding (Simons and Ehehalt, 2002; Munderloh et al., 2009). Recent evidence shows that microdomain scaffolding proteins are upregulated in fish RGCs upon optic nerve lesion (Schulte et al., 1997) and promote axon growth apparently by signals which affect the transport of bulk membrane and membrane proteins to the elongating growth cone (Munderloh et al., 2009; Stuermer, 2009). Direct information on microdomain switches of $\mathrm{NgR}$ or the putative second set of coreceptors is not yet available and is subject of future work. It also remains open whether the other Nogo-66 receptor, PirB (Atwal et al., 2008), is expressed in ZF RGC axons and involved in this growth/no growth scenario.

Anyhow, we have to postulate that the complex of NgR and coreceptors and the hypothetical preference of $\mathrm{NgR}$ for specific microdomains are regulated by the Nogo-66 ligands in mammals and fish, and in particular by the evolutionarily less-conserved second helix (supplemental Fig. 4, available at www.jneurosci.org as supplemental material). In conclusion, whether the NgRs (plus coreceptors) transduce signals for axon growth as opposed to inhibition is dependent on the origin of Nogo-66, from fish or mammal.

\section{Nogo-66 in the path of regenerating axons}

Such analysis is only meaningful if ZF rtn-4 is expressed in glial cells of the optic nerve. The presence of Nogo-66 in glial cells, RGC axons, and CNS myelin suggests that growth cones of regenerating axons that contact myelin and myelin debris repeatedly along their path to the brain (Strobel and Stuermer, 1994) can bind Nogo66 and profit from its growth-permissive/promoting property-so that ZF-Nogo66 might indeed be useful for growth of the regenerating axons in vivo. Moreover, the fact that
NgR signaling upon ZF-Nogo66 binding promotes growth predicts that additional ligands of $\mathrm{NgR}$ such as MAG, OMGP, and further myelin proteins negatively affecting axon growth in mammals (Yiu and He, 2006), probably have no or only weak inhibitory influence on axon growth in fish, or are simply absent (such as the NogoA-specific domain). In addition, fish possess their own myelin components such as the proteins $36 \mathrm{k}$ and IP-1 and IP-2 (Jeserich et al., 2008) that are absent from mammals. Furthermore, no glial scar-associated growth inhibition exists in goldfish (Hirsch et al., 1995) and glial cell-derived soluble factors actually support axon regeneration (Schwalb et al., 1996). On top of the growth-permissive nature of glial cells in the fish optic nerve the extraordinary neuron-intrinsic properties bring axotomized fish RGCs into an optimal growth state (Stuermer et al., 1992; Munderloh et al., 2009). The present data together with earlier results imply that the fish CNS is optimized for successful regeneration and thus could serve as a model for the identification of parameters required for robust axon regeneration in the CNS.

\section{Absence of axon growth inhibitors and plasticity}

The absence of Nogo inhibitors from the fish CNS correlates not only with axon regeneration but also with the remarkable plasticity of nerve connections in the fish retinotectal pathway (Gaze, 1970; Easter and Stuermer, 1984; Stuermer and Easter, 1984). Indeed, Nogo-A in mammals interferes with sprouting of CNS axons (Von Meyenburg et al., 1998; Buffo et al., 2000) and counteracts plasticity. It is tempting to speculate that fish RGC axon regeneration and the retinotectal plasticity might be less effective if the mammalian version of the Nogo gene would be expressed in the fish CNS. It is also conceivable that absence of inhibitory substrates permits the exploratory behavior of regenerating fish axons and the formation of the exuberant axon branches (Schmidt et al., 1988; Stuermer, 1988a,b) characteristic for fish RGC axons in vivo. In this context, functional analyses of the second Nogo-66 receptor PirB will be of interest in future work since PirB was reported to be crucial for ocular dominance plasticity (Syken et al., 2006). Finally, in light of the difference between the fish and tetrapod nogo genes, the question arises if tetrapods acquired an inhibitory version of Nogo-66 and-even more important-whether they gained Nogo-A during evolution; or whether fish lost Nogo-66 inhibition and the entire NogoA-specific domain.

\section{References}

Ankerhold R, Stuermer CA (1999) Fate of oligodendrocytes during retinal axon degeneration and regeneration in the goldfish visual pathway. J Neurobiol 41:572-584.

Atwal JA, Pinkston-Gosse, Syken J, Stawicki S, Wu Y, Shatz C, TessierLavigne M (2008) PirB is a functional receptor for myelin inhibitors of axonal regeneration. Science 323:967-970.

Barton WA, Liu BP, Tzvetkova D, Jeffrey PD, Fournier AE, Sah D, Cate R, Strittmatter SM, Nikolov DB (2003) Structure and axon outgrowth inhibitor binding of the Nogo-66 receptor and related proteins. EMBO J 22:3291-3302.

Bastmeyer M, Bähr M, Stuermer CA (1993) Fish optic nerve oligodendrocytes support axonal regeneration of fish and mammalian retinal ganglion cells. Glia 8:1-11.

Bastmeyer M, Beckmann M, Schwab ME, Stuermer CA (1991) Growth of regenerating goldfish axons is inhibited by rat oligodendrocytes and CNS myelin but not by goldfish optic nerve tract oligodendrocytelike cells and fish CNS myelin. J Neurosci 11:626-640.

Buffo A, Zagrebelsky M, Huber AB, Skerra A, Schwab ME, Strata P, Rossi F (2000) Application of neutralizing antibodies against NI-35/250 myelinassociated neurite growth inhibitory proteins to the adult rat cerebellum 
induces sprouting of uninjured Purkinje cell axons. J Neurosci 20:22752286.

Chen MS, Huber AB, van der Haar ME, Frank M, Schnell L, Spillmann AA, Christ F, Schwab ME (2000) Nogo-A is a myelin-associated neurite outgrowth inhibitor and an antigen for monoclonal antibody IN-1. Nature 403:434-439.

Chivian D, Kim DE, Malmström L, Schonbrun J, Rohl CA, Baker D (2005) Prediction of CASP6 structures using automated Robetta protocols. Proteins 61 [Suppl 7]:157-166.

Deininger SO, Rajendran L, Lottspeich F, Przybylski M, Illges H, Stuermer CA, Reuter A (2003) Identification of teleost Thy- 1 and association with the microdomain/lipid raft reggie proteins in regenerating CNS axons. Mol Cell Neurosci 22:544-554.

Diekmann H, Klinger M, Oertle T, Heinz D, Pogoda HM, Schwab ME, Stuermer CA (2005) Analysis of the reticulon gene family demonstrates the absence of the neurite growth inhibitor Nogo-A in fish. Mol Biol Evol 22:1635-1648.

Dodd DA, Niederoest B, Bloechlinger S, Dupuis L, Loeffler JP, Schwab ME (2005) Nogo-A, -B, and -C are found on the cell surface and interact together in many different cell types. J Biol Chem 280:12494-12502.

Domeniconi M, Cao Z, Spencer T, Sivasankaran R, Wang K, Nikulina E, Kimura N, Cai H, Deng K, Gao Y, He Z, Filbin M (2002) Myelinassociated glycoprotein interacts with the Nogo66 receptor to inhibit neurite outgrowth. Neuron 35:283-290.

Easter SS Jr, Stuermer CA (1984) An evaluation of the hypothesis of shifting terminals in goldfish optic tectum. J Neurosci 4:1052-1063.

Edgar RC (2004) MUSCLE: multiple sequence alignment with high accuracy and high throughput. Nucleic Acids Res 32:1792-1797.

Endo M, Ohashi K, Mizuno K (2007) LIM kinase and slingshot are critical for neurite extension. J Biol Chem 282:13692-13702.

Finn RD, Tate J, Mistry J, Coggill PC, Sammut SJ, Hotz HR, Ceric G, Forslund K, Eddy SR, Sonnhammer EL, Bateman A (2008) The Pfam protein families database. Nucleic Acids Res 36:D281-D288.

Fournier AE, GrandPre T, Strittmatter SM (2001) Identification of a receptor mediating Nogo-66 inhibition of axonal regeneration. Nature 409:341-346.

Fournier AE, Takizawa BT, Strittmatter SM (2003) Rho kinase inhibitor enhances axonal regeneration in the injured CNS. J Neurosci 23:1416-1423.

Gaze RM (1970) The formation of nerve connections. London: Academic.

GrandPré T, Nakamura F, Vartanian T, Strittmatter SM (2000) Identification of the Nogo inhibitor of axon regeneration as a Reticulon protein. Nature 403:439-444.

GrandPré T, Li S, Strittmatter SM (2002) Nogo-66 receptor antagonist peptide promotes axonal regeneration. Nature 417:547-551.

He XL, Bazan JF, McDermott G, Park JB, Wang K, Tessier-Lavigne M, He Z, Garcia KC (2003) Structure of the Nogo receptor ectodomain: a recognition module implicated in myelin inhibition. Neuron 38:177-185.

Hirsch S, Cahill MA, Stuermer CA (1995) Fibroblasts at the transection site of the injured goldfish optic nerve and their potential role during retinal axonal regeneration. J Comp Neurol 360:599-611.

Horn KP, Busch SA, Hawthorne AL, van Rooijen N, Silver J (2008) Another barrier to regeneration in the CNS: activated macrophages induce extensive retraction of dystrophic axons through direct physical interactions. J Neurosci 28:9330-9341.

Hsieh SH, Ferraro GB, Fournier AE (2006) Myelin-associated inhibitors regulate cofilin phosphorylation and neuronal inhibition through LIM kinase and Slingshot phosphatase. J Neurosci 26:1006-1015.

Jain E, Bairoch A, Duvaud S, Phan I, Redaschi N, Suzek BE, Martin MJ, McGarvey P, Gasteiger E (2009) Infrastructure for the life sciences: design and implementation of the UniProt website. BMC Bioinformatics 10:136.

Jeserich G, Klempahn K, Pfeiffer M (2008) Features and functions of oligodendrocytes and myelin proteins of lower vertebrates. J Mol Neurosci 35:117-126.

Klinger M, Taylor JS, Oertle T, Schwab ME, Stuermer CA, Diekmann H (2004) Identification of Nogo-66 Receptor $(\mathrm{NgR})$ and homologous genes in fish. Mol Biol Evol 21:76-85.

Koprivica V, Cho KS, Park JB, Yiu G, Atwal J, Gore B, Kim JA, Lin E, TessierLavigne M, Chen DF, He Z (2005) EGFR activation mediates inhibition of axon regeneration by myelin and chondroitin sulfate proteoglycans. Science 310:106-110.
Laurén J, Hu F, Chin J, Liao J, Airaksinen MS, Strittmatter SM (2007) Characterization of myelin ligand complexes with neuronal Nogo-66 receptor family members. J Biol Chem 282:5715-5725.

Letunic I, Copley RR, Pils B, Pinkert S, Schultz J, Bork P (2006) SMART 5: domains in the context of genomes and networks. Nucleic Acids Res 34:D257-D260.

Li M, Liu J, Song J (2006) Nogo goes in the pure water: solution structure of Nogo-60 and design of the structured and buffer-soluble Nogo-54 for enhancing CNS regeneration. Protein Sci 15:1835-1841.

Málaga-Trillo E, Solis GP, Schrock Y, Geiss C, Luncz L, Thomanetz V, Stuermer CA (2009) Regulation of embryonic cell adhesion by the prion protein. PLoS Biol 7:e55.

Meberg PJ, Bamburg JR (2000) Increase in neurite outgrowth mediated by overexpression of actin depolymerizing factor. J Neurosci 20:2459-2469.

Mi S, Lee X, Shao Z, Thill G, Ji B, Relton J, Levesque M, Allaire N, Perrin S, Sands B, Crowell T, Cate RL, McCoy JM, Pepinsky RB (2004) LINGO-1 is a component of the Nogo-66 receptor/p75 signaling complex. Nat Neurosci 7:221-228.

Munderloh C, Solis GP, Bodrikov V, Jaeger FA, Wiechers M, Málaga-Trillo E, Stuermer CA (2009) Reggies/flotillins regulate retinal axon regeneration in the zebrafish optic nerve and differentiation of hippocampal and N2a neurons. J Neurosci 29:6607-6615.

Niederöst B, Oertle T, Fritsche J, McKinney RA, Bandtlow CE (2002) Nogo-A and myelin-associated glycoprotein mediate neurite growth inhibition by antagonistic regulation of RhoA and Rac1. J Neurosci 22:10368-10376.

Oertle T, Klinger M, Stuermer CA, Schwab ME (2003a) A reticular rhapsody: phylogenic evolution and nomenclature of the RTN/Nogo gene family. FASEB J 17:1238-1247.

Oertle T, van der Haar ME, Bandtlow CE, Robeva A, Burfeind P, Buss A, Huber AB, Simonen M, Schnell L, Brösamle C, Kaupmann K, Vallon R, Schwab ME (2003b) Nogo-A inhibits neurite outgrowth and cell spreading with three discrete regions. J Neurosci 23:5393-5406.

Ott H, Diekmann H, Stuermer CA, Bastmeyer M (2001) Function of Neurolin (DM-GRASP/SC-1) in guidance of motor axons during zebrafish development. Dev Biol 235:86-97.

Park JB, Yiu G, Kaneko S, Wang J, Chang J, He XL, Garcia KC, He Z (2005) A TNF receptor family member, TROY, is a coreceptor with Nogo receptor in mediating the inhibitory activity of myelin inhibitors. Neuron 45:345-351.

Prinjha R, Moore SE, Vinson M, Blake S, Morrow R, Christie G, Michalovich D, Simmons DL, Walsh FS (2000) Inhibitor of neurite outgrowth in humans. Nature 403:383-384.

Schimmele B, Plückthun A (2005) Identification of a functional epitope of the Nogo receptor by a combinatorial approach using ribosome display. J Mol Biol 352:229-241.

Schmidt JT, Turcotte JC, Buzzard M, Tieman DG (1988) Staining of regenerated optic arbors in goldfish tectum: progressive changes in immature arbors and a comparison of mature regenerated arbors with normal arbors. J Comp Neurol 269:565-591.

Schrock Y, Solis GP, Stuermer CA (2009) Regulation of cell spreading, focal adhesion formation and filopodia extension by the cellular prion protein. FEBS Lett 583:389-393.

Schulte T, Paschke KA, Laessing U, Lottspeich F, Stuermer CA (1997) Reggie- 1 and reggie-2, two cell surface proteins expressed by retinal ganglion cells during axon regeneration. Development 124:577-587.

Schwab ME (2004) Nogo and axon regeneration. Curr Opin Neurobiol 14:118-124.

Schwalb JM, Gu MF, Stuermer C, Bastmeyer M, Hu GF, Boulis N, Irwin N, Benowitz LI (1996) Optic nerve glia secrete a low-molecular-weight factor that stimulates retinal ganglion cells to regenerate axons in goldfish. Neuroscience 72:901-910.

Silver J, Miller JH (2004) Regeneration beyond the glial scar. Nat Rev Neurosci 5:146-156,

Simons K, Ehehalt R (2002) Cholesterol, lipid rafts, and disease. J Clin Invest 110:597-603.

Solis GP, Hoegg M, Munderloh C, Schrock Y, Malaga-Trillo E, Rivera-Milla E, Stuermer CA (2007) Reggie/flotillin proteins are organized into stable tetramers in membrane microdomains. Biochem J 403:313-322.

Strobel G, Stuermer CA (1994) Growth cones of regenerating retinal axons contact a variety of cellular profiles in the transected goldfish optic nerve. J Comp Neurol 346:435-448. 
Stuermer CA (1988a) The trajectories of regenerating retinal axons in the goldfish tectum. I. A comparison of normal and regenerated axons at late regeneration stages. J Comp Neurol 267:55-68.

Stuermer CA (1988b) The trajectories of regenerating retinal axons in the goldfish tectum. II. Exploratory branches and growth cones on axons at early regeneration stages. J Comp Neurol 267:69-91.

Stuermer CAO (2009) The reggie/flotillin connection to growth. Trends Cell Biol, in press. Doi: 10.1016/j.tcb.2009.10.003.

Stuermer CA, Bastmeyer M, Bähr M, Strobel G, Paschke K (1992) Trying to understand axonal regeneration in the CNS of fish. J Neurobiol 23:537-550.

Stuermer CA, Easter SS Jr (1984) Rules of order in the retinotectal fascicles of goldfish. J Neurosci 4:1045-1051.

Syken J, Grandpre T, Kanold PO, Shatz CJ (2006) PirB restricts oculardominance plasticity in visual cortex. Science 313:1795-1800.

Vielmetter J, Stuermer CA (1989) Goldfish retinal axons respond to position-specific properties of tectal cell membranes in vitro. Neuron 2:1331-1339.

von Meyenburg J, Brösamle C, Metz GA, Schwab ME (1998) Regeneration and sprouting of chronically injured corticospinal tract fibers in adult rats promoted by NT-3 and the mAb IN-1, which neutralizes myelinassociated neurite growth inhibitors. Exp Neurol 154:583-594.

Wang KC, Kim JA, Sivasankaran R, Segal R, He Z (2002a) P75 interacts with the Nogo receptor as a co-receptor for Nogo, MAG and OMgp. Nature 420:74-78.

Wang KC, Koprivica V, Kim JA, Sivasankaran R, Guo Y, Neve RL, He Z (2002b) Oligodendrocyte-myelin glycoprotein is a Nogo receptor ligand that inhibits neurite outgrowth. Nature 417:941-944.

Wanner M, Lang DM, Bandtlow CE, Schwab ME, Bastmeyer M, Stuermer CA (1995) Reevaluation of the growth-permissive substrate properties of goldfish optic nerve myelin and myelin proteins. J Neurosci 15:75007508.

Waterhouse AM, Procter JB, Martin DM, Clamp M, Barton GJ (2009) Jalview Version 2 - a multiple sequence alignment editor and analysis workbench. Bioinformatics 25:1189-1191.

Z'Graggen WJ, Metz GA, Kartje GL, Thallmair M, Schwab ME (1998) Functional recovery and enhanced corticofugal plasticity after unilateral pyramidal tract lesion and blockade of myelin-associated neurite growth inhibitors in adult rats. J Neurosci 18:4744-4757.

Yiu G, He Z (2006) Glial inhibition of CNS axon regeneration. Nat Rev Neurosci 7:617-627. 